\title{
Impact assessment of climate change on potato productivity in Assam using SUBSTOR-Potato model
}

\author{
B. GOSWAMI ${ }^{1}$, R. HUSSAIN ${ }^{1}$, P.V. KUMAR ${ }^{2}$, U.S. SAIKIA ${ }^{3 *}$ and S. BANARJEE ${ }^{4}$ \\ ${ }^{1}$ Department of Agricultural Meteorology, AAU, Jorhat 785 013, Assam \\ ${ }^{2}$ Central Research Institute for Dryland Agriculture, Hyderabad 500059 \\ ${ }^{3}$ ICAR Research Complex for NEH Region, Umroi Road, Umiam 793 103, Meghalaya \\ ${ }^{4}$ Bidhan Chandra Krishi Viswa Vidyalaya, Kalyani 741 235, West Bengal \\ *Email: ussaikia73@gmail.com
}

\begin{abstract}
Potato tuber yield were simulated at Jorhat, Assam under various Representative Concentration Pathways (RCPs) scenarios for 2020, 2050 and 2080 using DSSAT SUBSTOR-Potato model. The model was calibrated and validated for three potato cultivars, viz., Kufri Jyoti, Kufri Pokhraj and Kufri Himalini with the experimental data collected during 2014-15 and 2015-16. Results revealed that if planting is delayed beyond November, all these cultivars are likely to record drastic reduction in tuber yield. Cultivar Kufri Himalini may incur tuber yield loss of 64 per cent in 2020 to 75 per cent in 2080, followed by Kufri Jyoti (57.6\% in 2020 to $71.5 \%$ in 2080) and Kufri Pokhraj (45.2\% in 2020 to $56.2 \%$ in 2080). Among the cultivars, Kufri Pokhraj may remain a viable cultivar up to 2050, but Kufri Himalini may lose its sustainability by 2020 itself. Hence, adjustment of planting time and development of improved adaptive potato cultivars only will ascertain future potato production in this region.
\end{abstract}

Key words: Climate change, RCP, potato yield variability, DSSAT SUBSTOR-Potato model

Potato is the most important non-grain field crop with a global production of 501 million tonnes in 2014 (FAO, 2014). However, potato production is likely to decline across many parts of the world by 2100 (Raymundo et al., 2014). But, Stockle et al. (2010) indicated that, taking into account the positive effect of $\mathrm{CO}_{2}$ and adaptation strategies on crop production might sustain the current production levels under future climate change conditions. The SUBSTOR-Potato model has been used extensively to evaluate effects of variability in climate (Patil et al., 2018) nitrogen (Snapp and Fortuna, 2003) and water (Malkia et $a l ., 2016$ ) for optimizing potato productivity and also for climate change studies (Franke et al., 2013).

IPCC (2013) projected the global temperature change based on various Representative Concentration Pathways (RCP). Their assessment suggests that the temperature change at the end of the $21^{\text {st }}$ century is likely to exceed $1.5^{\circ} \mathrm{C}$ relative to 1850-1900, for all RCP scenarios except RCP 2.6. Ravindranath et al. (2011) assessed the effects of climate change in the North East India with multiple socio-economic consequences and opined that since 80 per cent of the crop area is under rainfed agriculture in the region, present and future climate change and variability might potentially affect agriculture production here, by virtue of acute soil moisture deficit and lack of irrigation/water harvesting infrastructure. A study, based on standardized precipitation index, demonstrated the changes in overall seasonal proneness of the North East India to meteorological drying or wetting, and that most places of the region had suffered loss of monsoon wetness during 1991-2007 (Saikia et al.,2013). At Jorhat, Assam increase in both maximum and minimum temperatures, under different RCPs for 2020, 2050 and 2080, suggested increasing level of heat stress during crop growth period (Goswami et al., 2016). Under these circumstances, this study was taken up to evaluate the impact of climate change on potato production in Assam, which is a major potato growing area in the state.

\section{MATERIALS AND METHODS}

\section{Field experiment}

The field experiment was conducted at Jorhat, Assam ( $26^{\circ} 44^{\prime} \mathrm{N}$ latitude, $94^{\circ} 10^{\prime} \mathrm{E}$ longitude and $91 \mathrm{~m}$ above mean sea level), respectively during rabi seasons of 2014-15 and 2015-16 in a sandy clay loam soil (Table 1) with three cultivars of potato, viz., (Kufri Jyoti, Kufri Pokhraj and Kufri Himalini) and three dates of planting at 15 days interval (20 November, 6 and 22 December in 2014-15 and 19 November, 5 and 21 December in 2015-16) in a randomized 
Table 1: Soil physico-chemical properties of the experimental site

\begin{tabular}{|c|c|c|c|c|c|}
\hline Sl. No. & Parameters & \multicolumn{4}{|c|}{ Description } \\
\hline 1 & Soil colour & \multicolumn{4}{|l|}{ Grey } \\
\hline 2 & Soil texture & \multicolumn{4}{|c|}{ Sandy clay loam } \\
\hline 3 & Drainage & \multicolumn{4}{|c|}{ Moderately well } \\
\hline 4 & Soil series & \multicolumn{4}{|l|}{ Rowriah } \\
\hline 5 & Soil classification & \multicolumn{4}{|c|}{ Fine, mixed, hyperthermic family of Humic Endoaquepts } \\
\hline \multirow[t]{3}{*}{6} & Slope $(\%)$ & \multicolumn{4}{|c|}{ Nearly level to very gently sloping } \\
\hline & & \multicolumn{4}{|c|}{ Soil layers $(\mathbf{c m})$} \\
\hline & & $0-20$ & $20-48$ & $48-62$ & $62-100$ \\
\hline 7 & Clay $(\%)$ & 24.4 & 35.4 & 41.4 & 35.2 \\
\hline 8 & Silt $(\%)$ & 52.7 & 49.0 & 35.0 & 32.4 \\
\hline 9 & Sand $(\%)$ & 22.9 & 15.6 & 23.6 & 32.4 \\
\hline 10 & $\mathrm{p}^{\mathrm{H}}$ & 5.2 & 5.1 & 5.1 & 5.0 \\
\hline 11 & $\mathrm{CEC}\left(\mathrm{Cmol} \mathrm{Kg}{ }^{-1}\right)$ & 6.1 & 8.4 & 9.6 & 7.9 \\
\hline 12 & Organic C (\%) & 0.88 & 0.42 & 0.32 & 0.19 \\
\hline 13 & Soil moisture $(\% / \mathrm{v})$ & 24.4 & 25.5 & 26.8 & 28.8 \\
\hline
\end{tabular}

Table 2: Genotype coefficients of potato cultivars Kufri Jyoti, Kufri Pokhraj and Kufri Himalini at Jorhat

\begin{tabular}{llrrr}
\hline Symbol & Description & \multicolumn{2}{c}{ Genotype coefficients } \\
& & Kufri Jyoti & Kufri Pokhraj & Kufri Himalini \\
\hline G2 & Leaf area expansion rate (degree days) & 2000 & 2000 & 2000 \\
G3 & Potential tuber growth rate $\left(\mathrm{g} \mathrm{m}^{-2} \mathrm{day}^{-1}\right)$ & 25.5 & 25.5 & 18.0 \\
PD & Index that suppresses tuber growth during the & 0.5 & 0.6 & 0.5 \\
& period that immediately follows tuber induction & & 0.4 & 0.8 \\
P2 & Index that relates photoperiod response to tuber initiation & 0.8 & 20 & 18 \\
TC & Upper critical temperature for tuber initiation $\left({ }^{\circ} \mathrm{C}\right)$ & 18 & & \\
\hline
\end{tabular}

block design.Recommended dose of N, P and K fertilizers were applied. Row spacing of $50 \mathrm{~cm}$ was maintained with planting population of 10 plants $\mathrm{m}^{-2}$. Daily weather data were collected from the agrometeorological observatory of the Assam Agricultural University, Jorhat located adjacent to the experimental plot.

\section{Model calibration and validation}

The SUBSTOR-Potato model uses five genotype coefficients to define growth and development characteristics of a potato cultivar. The model calibration was done for three different cultivars with three dates of planting using 2014-15 field data sets comprising of nine treatments and three replications. Validation was carried out with optimized genotype coefficients using 2015-16 field data sets. The calibration and validation were done with respect to fresh tuber yield. RMSE and d-stat values of summary results were examined to determine the agreement between observed and simulated values.

\section{Climate change scenarios}

Four RCPs (2.6, 4.5, 6.0 and 8.5) were used, which were generated using Hadley Global Environment Model 2Earth System (HadGEM2-es) (Collins et al., 2011). RCP projected climatic data on daily maximum and minimum temperature, rainfall and solar radiation for 2020,2050 and 2080 were collected from Central Research Institute for Dryland Agriculture (CRIDA),Hyderabad. The simulated yields of different scenarios were compared with average observed yield of 2014-16.

\section{RESULTS AND DISCUSSION}

\section{Calibration and validation}

The optimized genotype coefficients of three potato 

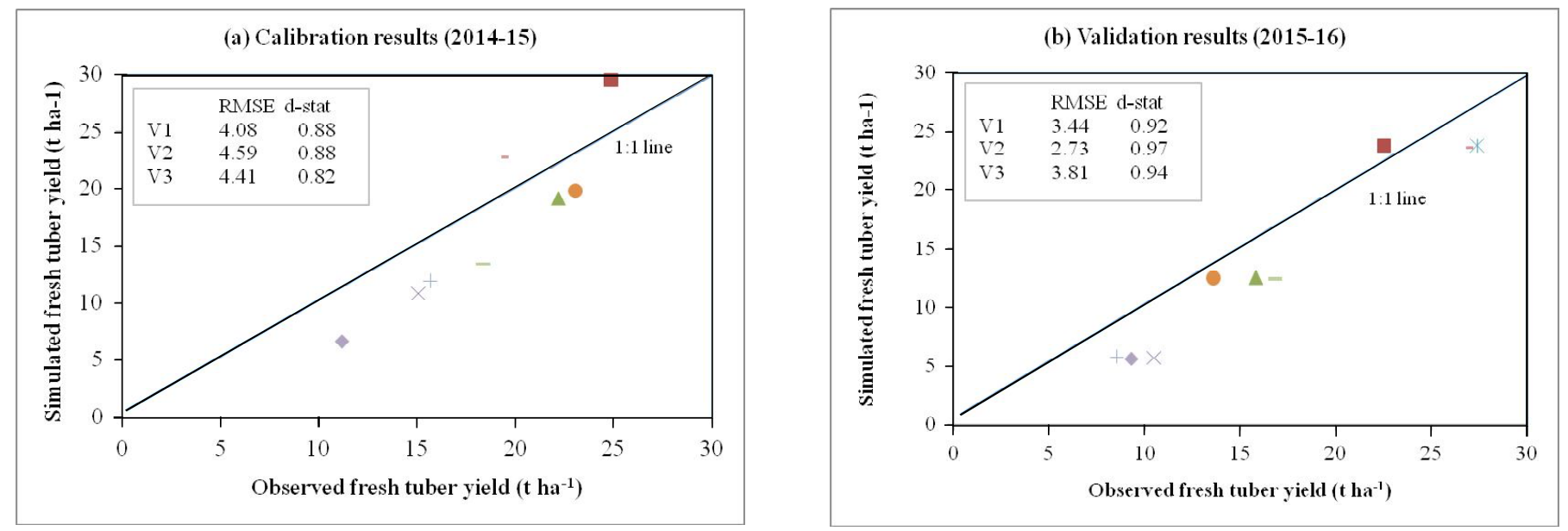

Fig. 1: Calibration (2014-15) and validation (2015-16) results of potato cultivars Kufri Jyoti, Kufri Pokhraj and Kufri Himalini at Jorhat (DSSAT SUBSTOR-Potato model)

cultivars, viz., K. Jyoti, K. Pokhraj and K. Himalini for the SUBSTOR-Potato model are presented in Table 2.The calibration (2014-15) and validation (2015-16) results for fresh tuber yield of three potato cultivars under three dates of planting are presented in Fig. 1. Low RMSE and d-stat $>0.5$ was observed in most cases of calibration and validation, which signifies very good agreements between observed and simulated values.

\section{Projected variations in fresh tuber yield of different cultivars}

Projected variations in fresh tuber yield of different cultivars at Jorhat under different projection periods and dates of planting, considering all RCPs together, is presented in Table 3. This is expressed as per cent difference over current observed mean yield (2014-15 and 2015-16). In the $1^{\text {st }}$ planting period (third week of November), the mean observed fresh yield recorded for Kufri Jyoti (V1), Kufri Pokhraj(V2) and Kufri Himalini (V3) were 23.7, 19.8 and $12.8 \mathrm{tha}^{-1}$, respectively. In this option of planting, cultivar $\mathrm{V} 1$ is likely to perform best in all projection periods, followed by V2. There is likely hike of fresh tuber yield by 33.8 (2020) to 18.1 per cent (2080) over the current mean yield for V1. Similarly cultivar V2 is likely to gain between 18.8 (2020) and 10.8 per cent (2080). In contrast, cultivar V3 is set to face reduction in its fresh tuber yield by $2.1(2020)$ to 14.7 per cent (2080).

In the $2^{\text {nd }}$ option of planting ( $1{ }^{\text {st }}$ week of December), the current mean tuber yields are 27.2, 18.3 and $12.1 \mathrm{t}$ $\mathrm{ha}^{-1}$ for V1, V2 and V3, respectively. Under projected scenarios, fresh tuber yield of cultivar V1 is likely to reduce by 7.1 (2020) to 30.1 per cent (2080). The yield of cultivar V3 will further go down by 37.6 (2020) to 52.7 per cent (2080). Whereas, cultivar V2 will maintain its gain in tuber yield by 9.8 (2020) to 10.7 per cent (2050), but is likely to record a loss of 16.1 per cent in 2080 over the current mean fresh tuber yield.

If planting is further delayed to $3{ }^{\text {rd }}$ week of December, all these cultivars are likely to record drastic reduction in tuber yield. The $\mathrm{V} 3$ may record highest loss of 64 (2020) to 75 per cent (2080), followed by V1 (57.6\% in 2020 to $71.5 \%$ in 2080) and V2 (45.2\% in 2020 to $56.2 \%$ in 2080). All of the present cultivars may not remain sustainable under this option of planting period and tuber yield is likely to fall by over 50 per cent from the current mean values. The reduction in future tuber yield may be attributed to possible increase in temperature. Basu and Minhas (1999) observed that high temperatures negatively affected the allocation of glucose, stimulated the growth of above ground biomass and simultaneously reduced tuber accumulation though not necessarily inhibit tuber initiation. Patil et al.(2018) have also reported reduction in tuber yield of potato in Gujarat by 6-17 per cent due to increase in maximum and minimum temperatures during different months of potato growing season.

Though the potato cultivars are not differing much in current yield realization within themselves, even then if planting is delayed, Kufri Himalini maynot remain suitable for planting beyond 2020 under all options of planting and Kufri Jyoti beyond 2050 under December planting in this region. Kufri Pokhraj is likely to remain as a viable cultivar under subtropical conditions of Jorhat till 2050 and can be planted up to $I^{\text {st }}$ week of December.

\section{CONCLUSIONS}

Validation of DSSAT SUBSTOR-Potato model, with 
Table 3:Projected variations in fresh tuber yield of potato cultivars under different projection periods and periods of planting over current mean observed yield (2014-15 and 2015-16) considering all RCPs together

\begin{tabular}{|c|c|c|c|c|c|}
\hline \multirow[t]{2}{*}{ Planting times (D) } & \multirow[t]{2}{*}{ Cultivars (V) } & \multirow{2}{*}{$\begin{array}{c}\text { Mean observed yield } \\
\left(\mathrm{t} \mathrm{ha}^{-1}\right)\end{array}$} & \multicolumn{3}{|c|}{ Change in tuber yield over current mean yield $(\%)$} \\
\hline & & & 2020 & 2050 & 2080 \\
\hline \multirow[t]{3}{*}{ 3rd Week of November } & Kufri Jyoti & 23.7 & 33.8 & 30.5 & 18.1 \\
\hline & Kufri Pokhraj & 19.1 & 18.8 & 18.5 & 10.8 \\
\hline & Kufri Himalini & 12.8 & -2.1 & -1.6 & -14.7 \\
\hline \multirow{2}{*}{ 1st Week of December } & Kufri Pokhraj & 18.3 & 9.8 & 10.7 & -16.1 \\
\hline & Kufri Himalini & 12.1 & -37.6 & -38.2 & -52.7 \\
\hline \multirow[t]{2}{*}{ 3rd Week of December } & Kufri Jyoti & 23.0 & -57.6 & -60.7 & -71.5 \\
\hline & Kufri Pokhraj & 17.6 & -45.2 & -46.3 & -56.2 \\
\hline
\end{tabular}

respect to low RMSE and high d-stat values for all the treatments, suggests good agreement between the observed and simulated results for three potato cultivars viz.,Kufri Jyoti, Kufri Pokhraj and Kufri Himalini under subtropical conditions of Jorhat. At present, Kufri Jyoti is the best performing cultivar followed by Kufri Pokhraj, but Kufri Himalini may not remain suitable for planting beyond 2020 under all options of planting and Kufri Jyoti beyond 2050 under December planting. However, Kufri Pokhraj is likely to remain as a viable cultivar under subtropical conditions of Jorhat till 2050 and will be suitable for planting up to $1{ }^{\text {st }}$ week of December. Delayed planting beyond November is likely to be economically unviable for potato cultivation in future scenarios.

\section{REFERENCES}

Basu P.S. and Minhas J.S. (1999). Tuberization at high temperatures in different potato genotypes, J. Ind. Potato Assoc., 26: 19-22.

Collins, W.J., Bellouin, N., Doutriaux-Boucher, M., Gedney, N., Halloran, P., Hinton, T., Hughes, J., Jones, C. D., Joshi, M., Liddicoat, S., Martin, G., O’Connor, F., Rae, J., Senior, C., Sitch, S., Totterdell, I., Wiltshire, A. and Woodward, S. (2011). Development and evaluation of an Earth-System model-HadGEM2. Geosci Model Dev, 4: 1051-1075, doi:10.5194/gmd-4-1051-2011.

FAO (2014). FAO Stat, http://www.fao.org/faostat/en/\#data/ QC as seen on 07-09-2017.

Franke, A.C., Haverkort, A.J. and Steyn, J.M. (2013). Climate change and potato production in contrasting South African agro-ecosystems 2: Assessing risks and opportunities of adaptation strategies, Potato Res.,56: 51-66.

Goswami, B., Hussain, R., Rao, V.U.M. and Saikia, U.S. (2016).Impact of climate change on rice yield at Jorhat, Assam. J. Agrometeorol., 18(2): 252-257.

IPCC. (2013). Climate Change 2013: The Physical Science Basis. Contribution of Working Group I to the Fifth Assessment Report of the Intergovernmental Panel on Climate Change [Stocker, T.F., D. Qin, G.-K. Plattner, M. Tignor, S.K. Allen, J. Boschung, A. Nauels, Y. Xia, V. Bex and P.M. Midgley(eds.)]. Cambridge University Press, Cambridge, United Kingdom and New York, NY, USA, pp. 1535.

Malkia, R., Hartani, T. and Dechmi, F. (2016). Evaluation of DSSAT model for sprinkler irrigated potato: Acase study of Northeast Algeria. African J. Agril. Res., 11: 25892598.

Patil, D. D., Pandey, V., Acharya, R. R. and Baraiya, L. N. (2018). Effect of intra-seasonal variation in temperature on tuberyield of potato in middle Gujarat using SUBSTOR model. J. Agrometeorol., 20(1): 22-27.

Ravindranath, N.H., Rao, S., Sharma, N., Nair, M. Gopalakrishnan, R. Rao, A.S., Malaviya, S., Tiwari, R. Sagadevan, A., Munsi, M, Krishna, N. and Bala, G. (2011). Climate change vulnerability profiles for North East India. Curr. Sci., 101(3):384-94.

Raymundo, R., Asseng, S., Cammarano, D. and Quiroz, R. (2014). Potato, sweet potato, and yam models for climate change: Areview, Field Crops Res.,166: 173-185. 
Saikia, U.S., Goswami, B., Rajkhowa, D.J., Venkatesh, A., Ramachandran, K., Rao, V.U.M, Venkateswarlu, B. and Ngachan, S.V.(2013). Shift in monsoon rainfall pattern in the North Eastern region of India post 1991. J. Agrometeorol.,15 (2) : 162-164.

Snapp, S.S. and Fortuna, A.M. (2003). Predicting nitrogen availability in irrigated potato systems. Hort. Technology, 13: 598-604.

Stockle, C.O., Nelson, R.L., Higgins, S., Brunner, J., Grove, G., Boydston, R., Whiting, M. and Kruger, C. (2010). Assessment of climate change impact on eastern Washington agriculture, Clim. Change,102: 77-102. 